This item was submitted to Loughborough's Research Repository by the author.

Items in Figshare are protected by copyright, with all rights reserved, unless otherwise indicated.

\title{
Why citizenship? Where, when and how children?
}

PLEASE CITE THE PUBLISHED VERSION

PUBLISHER

(c) The Cegla Center for Interdisciplinary Research of the Law

\section{LICENCE}

CC BY-NC-ND 4.0

\section{REPOSITORY RECORD}

Lister, Ruth. 2019. "Why Citizenship? Where, When and How Children?". figshare. https://hdl.handle.net/2134/3007. 
This item was submitted to Loughborough's Institutional Repository by the author and is made available under the following Creative Commons Licence conditions.

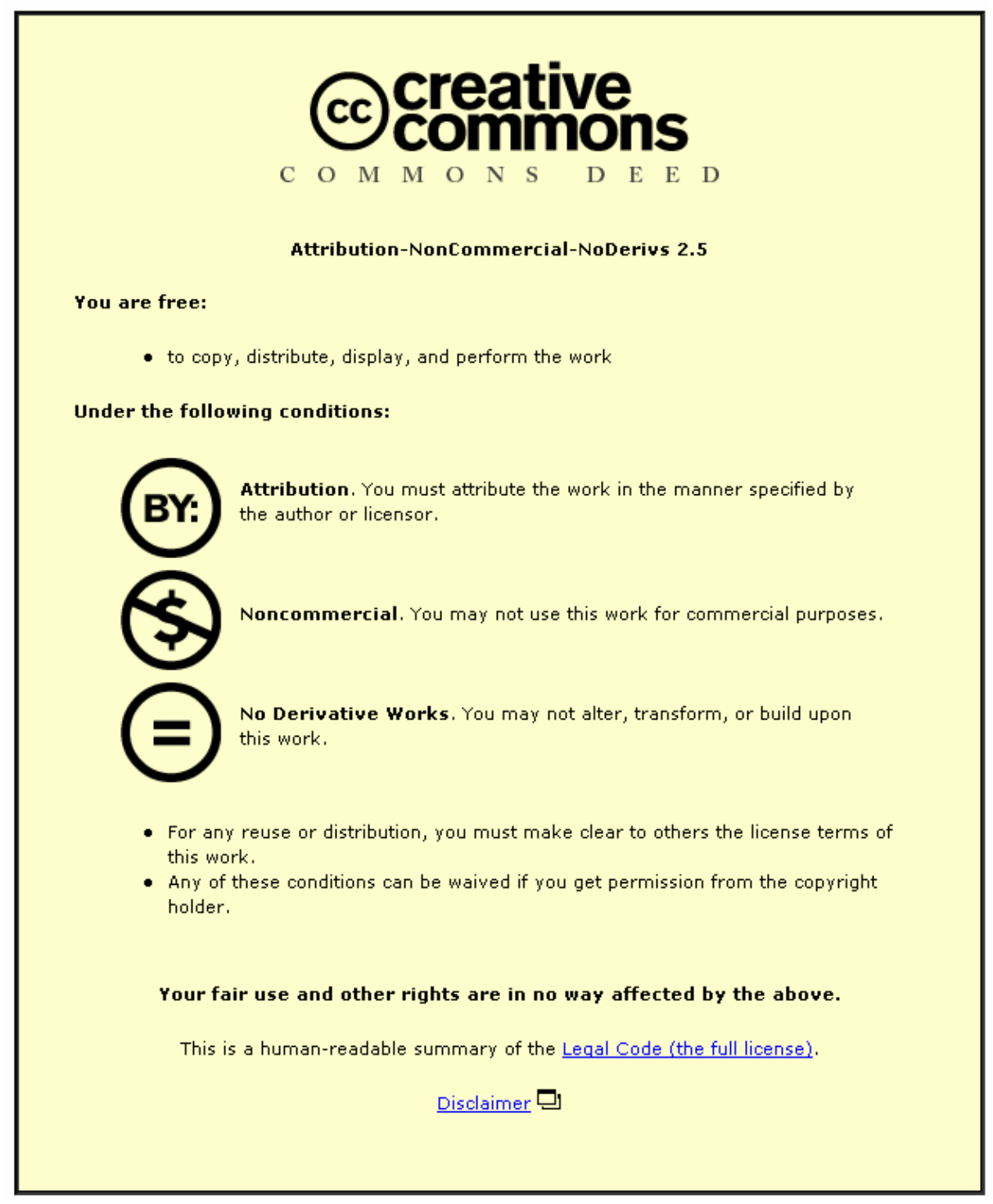

For the full text of this licence, please go to: http://creativecommons.org/licenses/by-nc-nd/2.5/ 


\title{
Why Citizenship: Where, When and How Children?
}

\begin{abstract}
Ruth Lister*
This Article addresses the general question of "why citizenship?" through the lens of children's citizenship. It unpacks the different elements of substantive citizenship and considers what they mean for children: membership and participation; rights; responsibilities; and equality of status, respect and recognition. It then discusses the lessons that may be learned from feminist critiques of mainstream constructions of citizenship, paying particular attention to the question of capacity for citizenship. It concludes by suggesting that much of the literature that is making the case for recognition of children as citizens is not so much arguing for the wholesale extension of adult rights and obligations of citizenship to children but recognition that children's citizenship practices constitute them as de facto, even if not complete de jure, citizens. More broadly, the Article argues that this position points towards an understanding of citizenship which embraces but goes beyond that of a bundle of rights.
\end{abstract}

* Ruth Lister is Professor of Social Policy in the Department of Social Sciences, Loughborough University, UK. She would like to thank the referees - Alexandra Dobrowolsky and Guy Mundlak - together with Sharon Bessell and the student editorial board for their very helpful comments on an earlier draft; and also participants in the Why Citizenship? workshop, University of Toronto, May 26-28, 2006, for their feedback on the initial paper. A much shorter version of this article will be published in CHILDREN AND CITIZENSHIP (Samantha Clutton et al. eds., forthcoming 2007). 


\section{INTRODUCTION}

"Why citizenship?" is the general question posed in this volume. This Article addresses the question through the lens of children's relationship to citizenship. An argument running through the Article is that the language of citizenship has a contribution to make over and above that of rights. This is spelled out in general terms in the Introduction. The Article then considers dominant representations of children's citizenship as a prelude to an analysis of the constituent components of substantive citizenship from the perspective of children and a discussion of the relevance of the feminist theorization of citizenship in this context. The Conclusion argues for the recognition of children's citizenship practices as part of a dialectical conceptualization of citizenship, which embraces but goes beyond the notion of a bundle of rights.

In the introduction to their Handbook of Citizenship Studies, Isin and Turner state that contemporary citizenship theory constructs citizenship not simply in terms of legal rights but "as a social process through which individuals and social groups engage in claiming, expanding or losing rights." This, they observe, has led "to a sociologically informed definition of citizenship in which the emphasis is less on legal rules and more on norms, practices, meanings, and identities." ${ }^{1}$ In a similar vein, from a feminist perspective, Werbner and Yuval-Davis argue that citizenship is no longer understood simply in terms of "the formal relationship between an individual and the state" but "as a more total relationship, inflected by identity, social positioning, cultural assumptions, institutional practices and a sense of belonging." 2 Part of that total relationship is the relationship between individual citizens, something that has been more prominent in the Scandinavian literature hitherto. ${ }^{3}$ It also involves responsibilities towards the wider community, an element of citizenship emphasized in more communitarian approaches and by politicians in a number of welfare states today.

These broader conceptualizations of citizenship lend themselves to the

1 Engin F. Isin \& Bryan Turner, Citizenship Studies: An Introduction, in HaNDBOOK OF CITIZENSHIP STUDIES 1, 4 (Engin F. Isin \& Bryan Turner eds., 2002).

2 Pnina Werbner \& Nira Yuval-Davis, Introduction: Women and the New Discourse of Citizenship, in WoMen, CitiZENSHIP AND DifFERENCE 1, 4 (Nira Yuval-Davis \& Pnina Werbner eds., 1999).

3 See, e.g., Helga Hernes, Welfare State and Woman Power (1987); Ruth LisTER ET AL., GENDERING CITIZENSHIP IN WESTERN EUROPE (2007). 
idea of "lived citizenship": "the meaning that citizenship actually has in people's lives and the ways in which people's social and cultural backgrounds and material circumstances affect their lives as citizens." ${ }^{4}$ The significance of rights-talk to lived citizenship is likely to vary according to political and cultural context, between groups and over time. The kind of dynamic, processoriented, understanding of rights, referred to by Isin and Taylor, is more likely to be salient in societies where rights are under-developed or are under threat or for groups who are denied full citizenship rights. A study of civil society activists in Brazil, for instance, found that although the majority "did not consider themselves to be treated as citizens, they did consider themselves to be citizens, primarily because they struggled for their rights." ${ }^{5}$ In contrast, a study of young people's citizenship in the UK found that very few of them thought of citizenship in terms of rights. ${ }^{6}$

A dynamic construction of rights, not only in terms of legal status but also as shaped through struggle, ${ }^{7}$ helps to open up the conversation between citizenship as a legal status and citizenship as a socio-political practice. Key here is the notion of human agency, which provides the link between conceptions of citizenship as an active, participatory practice and as a set of rights, which are the object of struggle. Citizenship as a practice represents an expression of human agency; citizenship as rights enables people to act as agents. ${ }^{8}$

Both analytically and politically, this dialectical understanding of citizenship is more fruitful than a focus on legal status alone. The rest of this Article will develop this argument from the perspective of children, a group that is increasingly calling for recognition as participating citizens yet whose status as citizens is not straightforward. Children who hold the legal status of citizens of their country of residence by virtue of birth are, for instance, entitled to one right symbolic of citizenship - the passport - but not to another - the vote. In contrast to many other contributions to this volume, which are concerned with citizenship's external boundaries, designed to exclude certain "outsiders" permanently, the focus here is on an

4 Tom Hall \& Howard Williamson, Citizenship ANd COMMUNity 2 (1999).

5 Evalina Dagnino, 'We All Have Rights, but ... ' Contesting Concepts of Citizenship in Brazil, in INCLusive CiTIZENSHIP 149, 156 (Naila Kabeer ed., 2005).

6 Ruth Lister et al., Young People Talk About Citizenship: Empirical Perspectives on Theoretical and Political Debates, 7 CiTIZENSHIP STUD. 235 (2003).

7 Celestine Nyamu-Musembi, Towards an Actor-Oriented Perspective on Human Rights, in INCLUSIVE CITIZENSHIP, supra note 5, at 31.

8 RUth Lister, Citizenship: Feminist PerspeCtives (2d ed. 2003); see also BiRTE SIIM, GENDER AND CITIZENSHIP (2000). 
aspect of citizenship's internal boundaries, through which all are expected to pass in time. ${ }^{9}$ The temporal reference is of particular significance because it points to a distinction between the entrenched exclusions faced by "outsiders" and second-class "insiders" on the one hand and the temporal restrictions on citizenship faced by children on the other.

\section{Representations of ChildRen's CitizenshiP}

Before analyzing the implications of these temporal restrictions, how is the question of children's citizenship represented in the existing literature? What follows is possibly something of a caricature, but the two extremes I will pose should help to identify dominant tendencies in writings about children and citizenship. On the one hand is the citizenship literature. This has only recently and very patchily started to address what citizenship means for children in the here and now. More typically, it has hitherto either tended to ignore children altogether, implicitly equating citizenship with adulthood, or has portrayed children as citizens of the future: variously described critically as "citizens-in-waiting," 10 "learner citizens,"11 or "apprentice citizens."12

T.H. Marshall, author of the classic post-war treatise on citizenship, referred to children and young people as "citizens in the making. ${ }^{13}$ In a chapter based on a study of young people's transitions to citizenship, I used this term. ${ }^{14}$ In a postscript to the chapter, Tom Burke, a 19-year-old student, criticized it as "fundamentally flawed." He argued that

it perpetuates a passive view of young people who are idly waiting for citizenship, and if they are lucky, it will be bestowed upon them by

9 Where the two overlap is in the case of the children of non-citizen residents whose rights are contingent upon those of their parents. See Adriana Kemp, Managing Migration, Reprioritizing National Citizenship: Undocumented Labor Migrants, Children and Policy Reforms in Israel, 8 THEORETICAL INQUIRIES L. 663 (2007).

10 David Cutler \& Roger Frost, Taking the Initiative: Promoting Young PeOPle's InVOLVEMENT IN PUBLIC DECISION-MAKING IN THE UK 8 (2001).

11 Madeleine Arnot \& Jo-Anne Dillabough, Introduction to CHALLENGING DEMOCRACY 1, 12 (Madeleine Arnot \& Jo-Anne Dillabough eds., 2000).

12 Michael Wyness et al., Childhood, Politics and Ambiguity: Towards an Agenda for Children's Political Inclusion, 38 Sociology 81, 82 (2004).

13 T.H. Marshall, Citizenship AND Social Class 25 (Cambridge Univ. Press 1st ed. 1950).

14 Ruth Lister et al., Young People and Citizenship, in Youth Policy And Social INCLUSION 33 (Monica Barry ed., 2005). 
others. It does not give young people their true credit as social actors in their own right nor does it recognise the contribution that young people are making to our society today . . . I am not a citizen in the making. I am a citizen today. ${ }^{15}$

While I would question whether the notion of "citizens in the making" necessarily carries all those connotations, the criticism does point to the dangers of future-oriented constructions of children and young people's citizenship. These are now quite dominant politically, particularly in the "social investment states" of the UK and Canada and in European Union discourse where children are typically constructed in instrumentalist terms as profitable investments who represent "citizen-workers of the future." ${ }^{16}$

At the other extreme, there is one strand in the childhood literature which challenges such future constructions by simply asserting that children are citizens. So, for example, a report from the UK Carnegie Young People Initiative, which covers children and young people aged ten and above, claims "they are citizens and should be treated as such."17 Of course, there is a wide space between these two extremes, which increasingly is being addressed by some of the literature, particularly the childhood literature but also more recently some of the citizenship literature. ${ }^{18}$

The childhood literature is important also because our understanding of children's relationship to citizenship is rooted in how we see children. The contemporary sociology of childhood's construction of children as social actors with agency and varying degrees of competence opens up possibilities for the recognition of children as active citizens in a way that a construction of them as passive objects of adult policies and practices did not. ${ }^{19}$ "Beings" are more easily seen as active citizens in the here and now

15 Tom Burke, Postscript on Citizenship, in Youth Policy And Social InClusion, supra note 14 , at 51, 53.

16 Typically, in "social investment states" the prioritization of policies such as earlyyears education and childcare are described as investments in society's future. See, e.g., Ruth Lister, Investing in the Citizen-Workers of the Future, 37 Soc. POL'Y \& ADMIN. 427 (2003); SANDY RUXTON, WHAT ABOUT Us? CHILDREN'S RIGHTS IN THE EUROPEAN UNION (2005).

17 CUTLER \& FROST, supra note 10, at 2.

18 This includes a number of articles in the key journal in the field, Citizenship Studies, all of which are referred to in this Article, infra notes 22, 29, 64.

19 STUdies In MODERN CHILdHoOd (Jens Qvortrup ed., 2005). 
than are "becomings," whose citizenship is seen as a potential and a status to be achieved in the future..$^{20}$

Children are also at times presented as a single category, particularly by politicians: "because the figure of the child is unified, homogeneous, undifferentiated, there is little talk about race, ethnicity, gender, class and disability. Children become a single, essentialized category." ${ }^{21}$ Yet, just as adults' relationship to citizenship is mediated by social divisions, such as class, gender, race, and disability, so is that of children. Children living in poverty face particular obstacles to citizenship. As with adults, this calls for a "difference-centered" theorization of citizenship. ${ }^{22}$ Although this Article only addresses difference from the perspective of age, the next step would be a more differentiated analysis of children's citizenship.

Age is especially significant for children's citizenship — not only because it serves to define the category but also because of its relationship to capacity within the category "children." Roche points to the distinction, drawn in much of the contemporary childhood literature, between "the younger child and the young person." "The arguments for the increased participation of children in decision-making affecting their lives are both practically and theoretically more compelling the older the child is," he concludes. ${ }^{23}$ However, the case is now also being made for the participation of younger children. ${ }^{24}$

A UNICEF report on The Evolving Capacities of the Child provides a compass to help navigate the difficult question of age and capacity. It points out that, while capacities evolve with age, in practice the actual ages at which a child acquires competencies vary according to her life experiences and social and cultural environment on the one hand, and the nature of the competencies and the situations in which they are required to be exercised on the other. At every stage, the report argues, there must be regard for "children's right to respect for their capacities" 25 and for children's agency. In practice, "adults consistently underestimate children's

20 Barbara Fawcett et al., Contemporary Child Care Policy and Practice (2005).

21 Alexandra Dobrowolsky, Rhetoric Versus Reality: The Figure of the Child and New Labour's Strategic 'Social Investment State,' 67 STUD. PoL. ECON. 43 (2002).

22 Mehmoona Moosa-Mitha, A Difference-Centred Alternative to Theorization of Children's Citizenship Rights, 9 CITIZENSHIP STUD. 369 (2005).

23 Jeremy Roche, Children: Rights, Participation and Citizenship, 6 CHILDHOOD 475, 483 (1999).

24 See infra Part III.

25 Gerison Lansdown, UNICEF, The Evolving CAPACITIES OF THE ChILD 15 (2005). 
capacities, ${ }^{26}$ raising questions about their ability to assess them. ${ }^{27}$ The specific question of citizenship capacity will be discussed below.

\section{UnPaCking ChILdREN's CitizenshiP}

Having considered children's relationship to citizenship in very general terms, the Article now turns to a question posed by Hill and Tisdall: "whether the concepts of 'childhood' and 'citizenship' are compatible. This question," they point out, "depends just as much on how 'citizenship' is defined as it does on childhood's definition. Certainly, a definition of 'citizenship' could be made that would definitely include children . . . . But would such a definition of 'citizenship' retain the basic building blocks of the concept?"28 This Part unpacks these basic building blocks: membership, rights, responsibilities and equality of status. As Cohen points out, there is a tendency in accounts of children's citizenship to treat one element of citizenship as if it were the whole, yet in its substantive form, citizenship is not a unitary, either/or phenomenon. ${ }^{29}$ It may be that some of the "building blocks" of citizenship are more compatible with childhood than others. In particular, simply to analyze children's citizenship from the perspective of rights, important as they are, would be to paint a very incomplete picture and one which fails to capture children's practices as citizens and the dialectic between those practices and their citizenship status.

\section{A. Membership}

On one level, children's claim to citizenship lies in their membership of the citizenship community. As explained earlier, this Article is concerned only with those children who have legal citizenship status in their country of residence. Their relationship to the citizenship community may be different from that of adults - in some ways weaker, particularly with regard to the national citizenship community, in some ways possibly stronger (through, for example, participation in the school community) and probably more localized. This does not, however, necessarily affect the claim to

26 Id. at 30-31.

27 E. Kay M. Tisdall et al., Listening to the Views of Children?, 24 J. SOC. WELFARE \& FAM. L. 385 (2003).

28 Malcolm Hill \& KaY Tisdall, ChILdREN AND SocieTy 38 (1997).

29 Elizabeth F. Cohen, Neither Seen nor Heard: Children's Citizenship in Contemporary Democracies, 9 CITIZENSHIP STUD. 221 (2005). 
membership. Membership is, in part, about a sense of belonging. In the British study of young people's transitions to citizenship, among those who understood citizenship in terms of membership some referred specifically to "a sense of belonging." ${ }^{30}$ This has been described as a "relational" definition of citizenship, found by one study to be more prevalent in the UK than the U.S., where the citizen was more likely to be defined in "non-relational" terms as the bearer of rights and duties. ${ }^{31}$ A relational understanding of citizenship may be particularly meaningful for children, especially in the context of the local community and institutions such as schools.

Much of the contemporary citizenship literature is preoccupied with the implications of citizenship for identity. Conover et al., for instance, describe citizenship as constituting "a fundamental identity that helps situate the individual in society." ${ }^{12}$ Hall et al. observe that "in the contemporary political and policy arena [in the UK], much of the rhetoric of citizenship is about citizenship as an identity - encouraging young people in particular to think about themselves as citizens." 33 The study of young people's transitions to citizenship found that identification with citizenship reflected a number of factors, including not just age but also social class, experience of paid work and community involvement, and more subjective factors such as feeling that one had been treated respectfully and had been able to have an effective say. ${ }^{34}$ This suggests that, while it is unlikely that citizenship will be a primary element in children's emergent fluid identities, it is more likely to be salient where they have experience of being treated respectfully as citizens and have had the opportunity to participate.

In an essay on children's citizenship, Jessica Kulynych draws on the work of Jürgen Habermas to argue that "the crucial axis of children's citizenship in the contemporary world is membership in the common political culture, and the key to children's citizenship lies in their incorporation into that political culture." ${ }^{35}$ For her, what is critical in the debate over

30 Lister et al., supra note 6.

31 Pamela J. Conover, Citizen Identities and Conceptions of the Self, 3 J. POL. PHIL. 133 (1995).

32 Pamela J. Conover et al., The Nature of Citizenship in the United States and Great Britain, 53 J. PoL. 800 (1991). For a theoretical discussion of citizenship and identity, see ENGIN F. ISIN \& PATRICIA K. Wood, CiTIZENSHIP AND IDENTITY (1999).

33 Tom Hall et al., Conceptualising Citizenship, Young People and the Transition to Adulthood, 13 J. EDUC. POL'Y 301 (1998).

34 Lister et al., supra note 6.

35 Jessica Kulynych, No Playing in the Public Sphere: Democratic Theory and the Exclusion of Children, 27 SOC. THEORY \& PRAC. 231, 232 (2001). 
children's citizenship is the development of citizenship as a political identity and "recognition of children as politically relevant beings." ${ }^{\text {"C Citizenship as }}$ membership thus also opens up an understanding of citizenship in relation to political identity and subjectivity, as developed and expressed through political participation, broadly defined. Roche equates "being counted as a member of the community" with participation and proposes that "the demand that children be included in citizenship is simply a request that children be seen as members of society too, with a legitimate and valuable voice and perspective. ${ }^{137} \mathrm{He}$ cites Martha Minow's observation that "including children as participants alters their stance in the community, from things or outsiders to members. ${ }^{138}$ This points to something of a conundrum: children can make their claim to be members of the citizen-community through active participation in it; but in order to be able to participate they first need to be accepted as members of the citizen-community. Yet that acceptance is, in practice, partly contingent on children demonstrating their capacity to be participatory citizens.

Evaluations of initiatives that have enabled children and young people to participate, as well as research into children's participation in social action groups, testify to how they "strengthen young people's sense of belonging to the community" as well as equipping them with the skills and capacities required for effective citizenship. ${ }^{39}$ This suggests that, while on one level, all children are members of the community and therefore have the status of citizens in a thin sense, recognition of children as citizens in the thicker sense of active membership requires facilitating their participation as political and social actors. This is about more than just participation in individual decisions about a child's own life made by parents and professionals. It also means participation in wider collective decision-making.

Increasingly, mechanisms are being developed throughout the world to enable such participation, albeit often patchily and with varying degrees of effectiveness, on the one hand, and tokenism, on the other. Examples include: children's parliaments and assemblies, children's participatory budget councils, and school councils. In a UNICEF report on children's participation, Gerison Lansdown cites a number of examples and comments on the lessons to be learned from them. For instance, she contrasts Children's

$36 I d$. at 242

37 Roche, supra note 23, at 479, 484.

38 Id. at 485

39 Cutler \& Frost, supra note 10, at 6; GERISON LANSDOWn, PROMOTING CHILDREN's Participation in Democratic Decision-Making (2001); KAREN EdEN \& Debi Roker, ‘ . . . Doing Something': Young People as Social Actors (2002); PERPETUA Kirby ET AL., BuILding A CUlture of PARTICIPATION (2003). 
Parliaments in Slovenia and Zimbabwe. In the former, tokenism was avoided by "politicians demonstrating that they were willing to listen, to give consideration to the proposals and issues raised by the children and act where possible." ${ }^{40}$ In response, the children developed "their own sense of democratic responsibility, as they recognised that they were being taken seriously. ${ }^{41}$ In the latter, the children themselves identified a range of factors that inhibited their capacity "to make a significant contribution to the political agenda" such as the lack of training, clear criteria for selection, and any follow-up to the parliament. ${ }^{42}$

Among the arguments that Lansdown delineates for children's participation are its contributions to strengthening democracy and to better decision-making. Support for the latter point can also be found in a collection of papers reporting on mechanisms in the global North and South, which demonstrates

the truly significant contributions that young people are able and eager to make - many of these contributions involve simple, practical suggestions with benefits not just for children but also for others in their communities .... It is clear from these papers that inclusion, consultation and the delegation of responsibility to children and youth can have very practical benefits, and that young people can contribute a unique and often unexpected and independent perspective. ${ }^{43}$

However, the editor also cautions against treating "the voice of young people as a panacea," for "there is plenty of evidence here that simply establishing participatory structures and opportunities for young people is no guarantee of their effectiveness. ${ }^{44} \mathrm{~A}$ critical factor is whether such structures allow "scope for meaningful action. ${ }^{45} \mathrm{He}$ suggests that education "in the values and skills of citizenship" is most likely to be effective if children "can actually use these skills to make a difference. ${ }^{46}$ Important too for the experience of citizenship is

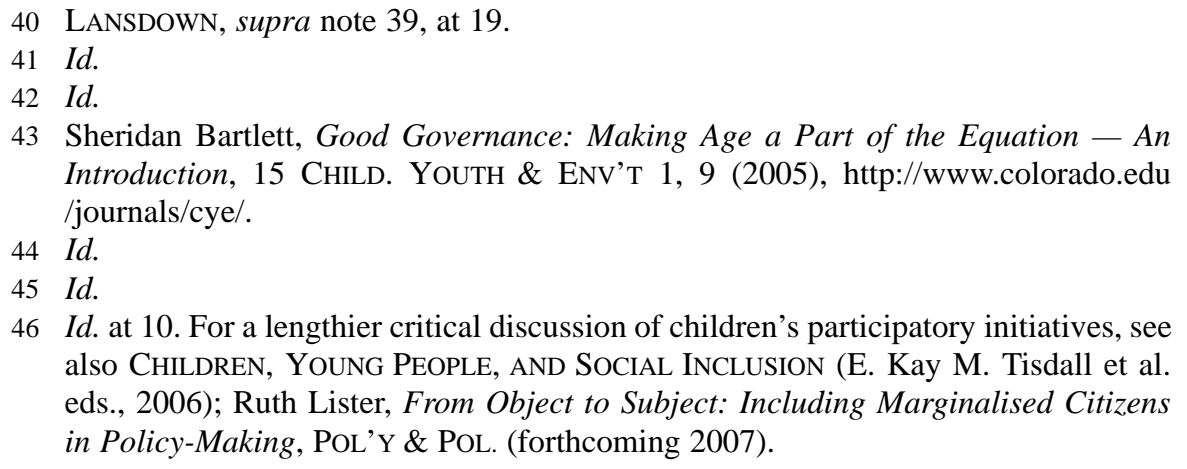

$46 I d$. at 10. For a lengthier critical discussion of children's participatory initiatives, see also Children, Young People, And Social Inclusion (E. Kay M. Tisdall et al. eds., 2006); Ruth Lister, From Object to Subject: Including Marginalised Citizens in Policy-Making, POL'Y \& POL. (forthcoming 2007). 
the quality of the relationships involved in participatory initiatives. According to Neale,

without due recognition and respect, participation may become an empty exercise, at best a token gesture or, at worst, a manipulative or exploitative exercise. "Real" citizenship, then, involves a search for ways to alter the culture of adult practices and attitudes in order to include children in meaningful ways and to listen and respond to them effectively. ${ }^{47}$

This underlines the importance of adults' behavior and manner of relating to children. They have the primary responsibility for the development of participatory structures and cultures that are genuinely inclusive of children. ${ }^{48}$ Their own continued responsibilities within the participation process need to be acknowledged. ${ }^{49}$

Ben-Arieh and Boyer explicitly equate participation with child citizenship and assert that its denial is unacceptable from the perspective of children's well-being and current and future citizenship. ${ }^{50}$ They argue that "if children are denied the right for participation, the onus of blame must lay on the shoulders of those denying that right." ${ }^{51}$ Participation thus represents both a citizenship practice and a (moral) right — at the heart of the dialectics of citizenship.

\section{B. Rights}

For T.H. Marshall, rights (civil, political and especially social) were a pivotal element of membership of the citizenship community. ${ }^{52}$ Children's right to participation, however, derives from the U.N. Convention on the Rights of the Child. ${ }^{53}$ The right to express an opinion and to have that opinion taken into

47 Bren Neale, Introduction: Young Children's Citizenship, in Young CHILDREN's Citizenship 6, 9 (Bren Neale ed., 2004).

48 See, e.g., Ruth Marchant \& Perpetua Kirby, The Participation of Young Children, in Young CHILDREN's CITIZENSHIP, supra note 47, at 92.

49 Gerison Lansdown, International Developments in Children's Participation: Lessons and Challenges, in ChildRen, Young People ANd Social InClusion, supra note 46, at 139.

50 Asher Ben-Arieh \& Yifat Boyer, Citizenship and Childhood, 12 CHILDHOOD 33, 51 (2005).

51 Id. at 50.

52 MARSHALL, supra note 13.

53 Convention on the Rights of the Child, Nov. 20, 1989, 1577 U.N.T.S. 3, 28 I.L.M. 1448 (entered into force Sept. 2, 1990). 
account in any matter or procedure affecting the child is enshrined in article 12 of the Convention. The extent to and manner in which this right is translated into enforceable rights of citizenship varies between countries. In the UK, such a right is contained in various pieces of children's legislation. There is not, though, a wider general right to participation for either children or adults. Arguably, participatory rights are of particular significance for children and young people because they cannot express voice through the ballot box. As the U.N. Committee on the Rights of the Child observes, "given that few States as yet have reduced the voting age below 18 , there is all the more reason to ensure respect for the views of unenfranchised children in Government and parliament." 54

It is the lack of the vote that perhaps raises the biggest question mark over the status of children's citizenship. The right to vote in national elections is what divides denizens (people with a legal and permanent residence status) from citizens, since denizens, in theory, normally enjoy full social and civil rights. It could be argued that without the vote a person is not a full citizen. As against that, in the UK at least, the vote does not seem to figure very prominently in public understandings of citizenship. Moreover, given low turnout in recent UK elections, particularly among young people, participation in informal politics, social action or public decision-making that affects their lives may constitute a more important signifier of effective lived citizenship for many people.

That, however, is not a reason for dismissing the issue of children's right to the vote. In the UK, the possibility of reducing the voting age from eighteen to sixteen is increasingly being mooted. The independent Power Inquiry recently recommended reduction of the voting and candidacy age to sixteen. Its report comments on "the contrast between the very low involvement of young people in formal democracy and their very active and serious-minded involvement in the innovations in participation explored by the Inquiry." ${ }^{55}$ This indicates the need to include young people "in the political process as early as is reasonably possible in order to sow the seeds of democracy and empowerment that will create a basis for engagement later in life. ${ }^{156}$ Others have made the case for a much wider extension of the franchise to children. ${ }^{57}$ The study of transitions to citizenship found that young people themselves

54 Committee on the Rights of the Child, General Comment No. 5 (2003): General Measures of Implementation of the Convention on the Rights of the Child, U.N. Doc. CRC/GC/2003/5 (Nov. 27, 2003), cited in RuXTON, supra note 16, at 132.

55 POWER INQuiry, Power to THE PEOPLE 199 (2006).

$56 I d$. at 200.

57 See, e.g., Stein Ringen, Citizens, FAMiLies And Reform (1997). 
were pretty evenly divided on the question of the voting age. Some did not favor lowering it because they believed they lacked the necessary knowledge to vote responsibly. Those who did want a reduction felt that without it they were not being listened to or respected and that the vote would help them to feel that they belonged and that they had a say as "full" or "proper" citizens. ${ }^{58}$

The rights contained in the U.N. Convention constitute universal human rights articulated specifically in relation to children. As such, they represent ethical or moral rights rather than directly legally enforceable rights (unless incorporated into national law) and are distinguishable from adult citizenship rights, from many of which children are excluded, in individual nation-states. Nevertheless, they provide "an important advocacy tool, a weapon to use in battles to secure recognition." ${ }^{59}$ As such, they offer a resource for citizenship, although one which is jeopardized by poverty and marginalizing social divisions.

Marshall wrote of education as a "genuine social right of citizenship." However, he argued that "fundamentally it should be regarded, not as the right of the child to go to school, but as the right of the adult citizen to have been educated." ${ }^{60}$ The other main social citizenship right to carry legally enforceable entitlements is social security. It is a right which children receive only "by proxy" through their parent(s) and which, in the UK, has become increasingly age-structured ${ }^{61}$ Typically, children acquire different citizenship rights (civil, political and social) at different ages - before, at and after the age of majority. This reflects how "age is the key determinant in the acquisition of formal rights in many societies" even though this inflexible model "does not reflect children's actual and differing capacities." ${ }^{62}$ With regard to civil rights, Cohen suggests that many of the classical civil rights are typically "regarded as irrelevant or inappropriate to the circumstances of childhood."63

Children's disqualification from adult citizenship rights is justified on grounds of their need for protection and their dependence on adults. Few would question that some distinction is valid on those grounds. That does not mean, though, that current configurations of their rights are necessarily

58 Unpublished data from Economic and Social Research Council Project L134 25 1039 (2002).

59 Michael Freeman, Beyond Rhetoric: Extending Rights to Young People, in YouTH POLICY AND SOCIAL InCluSION, supra note 14, at 55, 66.

60 MARSHALL, supra note 13, at 25.

61 Gill Jones and Claire Wallace, Youth, Family and Citizenship 49 (1992).

62 LANSDOWN, supra note 25, at 49-50.

63 Cohen, supra note 29, at 224. 
logical or appropriate from the point of view of the acquisition of full citizenship status, particularly in relation to what has been called today's "responsibilized" child. ${ }^{64}$ Interestingly, in the transitions to citizenship study mentioned earlier, the young people found it much harder to articulate their rights as citizens than they did their responsibilities. ${ }^{65}$ This may partly reflect the British context, in which successive recent governments have promoted responsibilities and obligations over rights.

\section{Responsibilities}

There are two overlapping aspects to children's responsibilities as citizens: those that are imposed (by law) and/or encouraged by the state, and those that children exercise of their own accord. As citizenship is increasingly interpreted as involving responsibilities as well as rights, it is important not to lose sight of this element when discussing children's citizenship. Indeed, the evidence of the responsibilities that many children exercise can be used in support of their claims for more effective rights.

A key imposed minimal responsibility of citizenship is to obey the law. ${ }^{66}$ In the UK, the effective age of criminal responsibility is now only ten in England and Wales, and eight in Scotland, in defiance of the recommendations of the U.N. Committee on the Rights of the Child. ${ }^{67}$ Children are a prime target of anti-social behavior orders and they can now be subject to special "child curfews." ${ }^{68}$ However, policy is not consistent. Such and Walker contrast the responsibilities attributed to children in crime and anti-social behavior policies with the lack of responsibility accorded them in family policy. They observe that "it is notable that children appear only to be granted agency and autonomy in the context of wrong-doing: children are able to be willfully irresponsible

64 Daiva Stasiulis, The Active Child Citizen: Lessons from Canadian Policy and the Children's Movement, 6 CITIZENSHIP STUD. 507, 509 (2002).

65 Lister et al., supra note 14.

66 In some countries in the global South, children are used as soldiers. Although military service was a traditional duty of citizenship, in countries such as the UK where it simply represents a career choice, this is no longer the case.

67 Committee on the Rights of the Child, Concluding Observations of the Committee on the Rights of the Child: United Kingdom of Great Britain and Northern Ireland, U.N. Doc. CRC/C/15/Add.188 (Oct. 9, 2002).

68 Anti-social behavior orders (or ASBOs) are penalties imposed by civil law in response to repeated anti-social behavior; failure to comply with their requirements can lead to a criminal charge including a jail sentence of up to five years. Hitherto, nearly half have been imposed on children aged under sixteen. They have been the subject of considerable controversy. 
but not willfully responsible. ${ }^{69}$ Their article reports on an exploratory study of children's own understandings of responsibility in the context of family life. They conclude that "responsibility is a meaningful and everyday aspect of many children's lives. To shy away from recognising this ... serves to deny children social citizenship."70

It is possible to point to examples of how children assume responsibility in both the private and public spheres, undertaking various forms of work, although this varies according to factors such as cultural and socio-economic context and gender. ${ }^{71}$ In the private sphere, an important example highlighted in the literature is the heavy responsibility taken on by children who assume the role of young carers. ${ }^{72}$ In the public sphere, a number of research studies as well as media reports reveal a fair amount of formal and informal volunteering and social action among children and young people. ${ }^{73}$ In many countries in the global South, children have to take on a range of adult responsibilities in both private and public spheres, particularly in countries where their families have been ravaged by HIV-AIDS.

Some children also exercise responsibility as political citizens in both national and global contexts. A review of children as actors in the development process gives examples of children's "political and social activism, whether on their own behalf, on behalf of their communities, or other children, or in support of an idea or principle. Children have acted as defenders of equality and justice . . . [and] as defenders of nationhood." 74 Writing about the international children's organization, Free the Children, Stasiulis suggests that the emergent children's movement "advances a view of children as empowered, knowledgeable, compassionate and global citizens." ${ }^{75}$ She characterizes the children's movement as enacting

69 Elizabeth Such \& Robert Walker, Young Citizens or Policy Objects?, 34 J. Soc. POL'Y 39, 46 (2005).

$70 \quad I d$. at 54-55.

71 Pavla Miller, Useful and Priceless Children in Contemporary Welfare States, 12 Soc. Pol. 3 (2005); Viviana A. Zelizer, The Priceless Child Revisited, in STUDIES IN MODERN CHILDHOOD, supra note 19, at 184.

72 Chris Dearden \& Saul Becker, Growing Up Caring, in Youth Policy AND Social INCLUSION, supra note 14, at 251.

73 See, e.g., Noel Smith et al., Young People as Real Citizens: Towards an Inclusionary Understanding of Citizenship, 8 J. YOUTH STUD. 425 (2005).

74 Jo Boyden \& Deborah Levisen, Children as ECONOMiC AND Social ACTORS IN THE DeVelopment PROCESs 44 (2000); see also Emma Williams, Small Hands, Big Voices: Children's Participation in Policy Change in India, 36 IDS Bull. 82 (2005).

75 Stasiulis, supra note 64, at 507. 
an "imaginary of children's active citizenship . . . [which] promotes cosmopolitan democratic values and a sense of responsibility and empathy among children in the North for the lives of children in the South who have been devastated by corporate globalization and adult greed. ${ }^{176}$ Children of the South have themselves organized across national frontiers, for instance through the International Movement of Working Children - a solidarity movement, which has demanded that working children's voices be heard in debates about child labor. ${ }^{77}$ Here children have created their own "popular spaces" of participation ${ }^{78}$ or "children's spaces. ${ }^{179}$ Kulynych contends that if actions in such spaces "are recognized as important forms of participation, then the activities in which children are already engaged can more easily be appreciated, and children themselves can more easily be visible as political actors." 80

Participation can promote responsibility. An account of a children's participatory budget council in Brazil observes that the majority of the children involved "feel that participating in the project ' . . . helps us to be more responsible not only at school but at home too." 81 Another study of this participatory budget council and similar initiatives in Latin America found that "it became clear to adults that youth is not an impediment to the assumption of collective responsibilities." 82 The author suggests that "the proven capacity of children to assume responsible roles can do as much as anything to promote respect for their particular perspective." 83

$76 \quad I d$. at 532.

77 Protagonism, The International Movement of Working Children, www.workingchild.org/prota2.htm (last visited Jan. 1, 2007).

78 Andrea Cornwall, Introduction: New Democratic Spaces?, 35 IDS Bull. 1, 2 (2004).

79 Peter Moss, From Children's Services to Children's Spaces, in ChILdREn, Young PeOPle And Social InClusion, supra note 46, at 179, 186; Malcolm Hill et al., Moving the Participation Agenda Forward, 18 CHILD. \& SoC'Y 77, 84 (2004).

80 Kulynych, supra note 35 , at 263. See also the discussion of participation, supra Section II.A.

81 Eliana Guerra, Citizenship Knows No Age: Children's Participation in the Governance and Municipal Budget of Barra Mansa, Brazil, 15 CHILD. Youth \& ENV'T 151, 161 (2005), http://www.colorado.edu/journals/cye/.

82 Yves Cabannes, Children and Young People Build Participatory Democracy in Latin American Cities, 15 ChILD. Youth \& ENV'T 185, 206, http://www.colorado.edu/journals/cye/.

83 Id. at 208. 


\section{Equality of Status, Respect and Recognition}

To treat others with respect is seen by the British public as a major responsibility of citizenship. ${ }^{84}$ It is one that children are as capable of exercising as anyone else. Conversely, Neale defines citizenship for children "as an entitlement to recognition, respect and participation." 85 Accounts "from below" identify recognition and respect - both for what humans hold in common and for their differences - as key elements of inclusive citizenship. ${ }^{86}$ Yet, as hinted at above, a common theme in the literature is the lack of recognition and respect for the responsibilities that children and young people exercise. This reflects a wider sense that children are not respected and therefore do not enjoy genuine equality of status as citizens. This is particularly true of children brought up in poverty, since poverty itself all too often is met with disrespectful treatment, and the effects on children can be especially wounding. ${ }^{87}$

\section{Lessons from the Feminist CritiQue}

As has been argued elsewhere with reference to gender and citizenship, "lack of recognition implies exclusion and marginalisation from 'full participation' in the community." 88 The emergent children's movement can be understood as a struggle for recognition. This leads to the possible parallels between the feminist critique and the critiques of children's relationship to citizenship. Wintersberger suggests that "gender studies have been a major source of inspiration and enlightenment for childhood studies," particularly with regard to women's movements' "questioning [of] the stranglehold of patriarchy." ${ }^{\text {" }}$

84 Development and Statistics Directorate, Home Office Research, 2003 Home OfFice Citizenship Survey (2004); Matthew Almond, An Investigation into the Meanings of Good Citizenship (2005) (unpublished Ph.D. dissertation, Loughborough University) (on file with the Pilkington Library).

85 Neale, supra note 47, at 1.

86 Naila Kabeer, The Search for Inclusive Citizenship, in INCLUSIVE CITIZENSHIP, supra note 5 , at 1 .

87 Ruth Lister, Poverty (2004); see also Tess Ridge, Childhood Poverty AND SOCIAL EXCLUSION (2002).

88 Barbara Hobson \& Ruth Lister, Citizenship, in CONTESTED CONCEPTS IN GENDER AND Social Politics 23, 41 (Barbara Hobson et al. eds., 2002).

89 Helmut Wintersberger, Work, Welfare and Generational Order: Towards a Political Economy of Childhood, in STUDIES IN MODERN CHILDHOOD, supra note 19, at 201, 214. 
Feminist citizenship theory illuminates a number of aspects of children's citizenship, although this does not mean that it is possible simply to transpose the feminist critique without adaptation.

\section{A. Capacity}

First, just as feminists have exposed the male template underpinning traditional meanings of citizenship, ${ }^{90}$ so can we argue that it is an adult template which measures children against an adult norm and ignores the particularities of children's relationship to citizenship. The difference is that, today, citizenship's universalism is supposed to cover women, at least in theory, whereas mainstream accounts of citizenship do not typically make any claims to include children.

The reasons used to justify women's earlier exclusion from citizenship are very similar to those used to justify children's exclusion today: notably their lack of competence, in particular to be rational, and their dependency. ${ }^{91}$ In response, both the definition of capacity and dominant assumptions about children's lack of it are under challenge. Hill and Tisdall, ${ }^{92}$ for instance, question the use of rationality as a criterion, pointing out that adults do not necessarily always act rationally in decision-making, whatever their capacities. Alderson states that "competence seems to be as much in the eye of the beholder as the ability of the child."93 This, she suggests, points to a need to develop new ways of defining and assessing children's competence. According to the UNICEF report, most of the thinking on this has been in relation to medical consent. ${ }^{94}$ What is needed is the same kind of assessment of the capacities necessary for citizenship.

A priori assumptions about age-related citizenship capacity have increasingly come under challenge. The Carnegie report points to the ability of children aged three or four "to express views about their immediate environment" and "to well tested methods . . . to listen to and analyse these views." 95 In their contribution to another UK report, which focuses on under-12-year-olds and in particular those aged 0-7, Marchant and Kirby

90 LISTER, supra note 8.

91 See Ratna Kapur, The Citizen and the Migrant: Postcolonial Anxieties, Law and the Politics of Exclusion/Inclusion, 8 THEORETICAL INQUIRIES L. 537 (2007).

92 HiLl \& TisDall, supra note 28.

93 Priscilla Alderson, Rights of Children and Young People, in THE Welfare OF Citizens 153, 175 (Anna Coote ed., 1992).

94 LANSDOWN, supra note 25.

95 CUTLER \& FROST, supra note 10, at 80. 
are critical of the way this group is rendered invisible as citizens and of the assumption that it is only older children who can participate as citizens. They argue that "young children have different competencies to older children and adults, but they are not inherently incompetent." ${ }^{16}$ In her introduction, Neale points out that the inclusion of older children and young people is relatively straightforward. They are expected to assume "'adult' modes of behaving and communicating," so that "it requires little change on the part of adults." "Citizenship for young children, on the other hand," she argues, "requires some effort on the part of adults to accommodate children's varied modes of doing, saying and being." 97

While there may nevertheless be a legitimate empirical question concerning the competence for citizenship of babies and very young children, the developmental nature of childhood competence is elided by a dichotomous counterpoising of maturity and competence against immaturity and incompetence. In this way, Wintersberger argues, "although sex and age relations are of fundamentally different nature, both gender and generational relations use dichotomies, which are more open to discrimination, marginalization and exclusion." ${ }^{198}$ It is just such dichotomies that the feminist citizenship literature has challenged. ${ }^{99}$

As observed earlier, there are countless instances of where children have shown themselves to be competent in the skills and capacities required for participation as citizens in different kinds of political spaces - from, for instance, children's parliaments to schools. At the same time, as Alderson has pointed out, "treating children with respect can markedly increase their competence." 100 Moreover, the UNICEF report suggests that "like adults, children build competence and confidence through direct experience: Participation leads to greater levels of confidence, which in turn enhances the quality of participation." ${ }^{101}$ Participation, also, the report argues, helps to develop a sense of autonomy and independence. However, as in the feminist context, this is less likely to be the case where participation is tokenistic. ${ }^{102}$

96 Ruth Marchant \& Perpetua Kirby, The Participation of Young Children: Communication, Consultation and Involvement, in YOUNG CHILDREN's CITIZENSHIP, supra note 47, at 92, 127-28.

97 Neale, supra note 47 , at 15.

98 Wintersberger, supra note 89, at 215.

99 LISTER, supra note 8.

100 Alderson, supra note 93, at 175.

101 LANSDOWN, supra note 25, at 17.

102 See supra Section II.A. 


\section{B. (In)dependence}

The treatment in the literature of dependence as an obstacle to children's citizenship echoes some of the arguments in the feminist literature. Writing about young people, Jones and Wallace explicitly draw parallels to argue that the extended dependence of young people as a result of policy developments in the UK in the late twentieth century has damaged their status as citizens. More recently, Jones and Bell claim that "citizenship is meaningless without economic independence." ${ }^{103}$ Children in industrialized societies lack it completely, except for whatever part-time wages they may earn.

As noted, any social security rights for children are by proxy. A key feminist policy argument has been that women's right to social security should be individualized and not mediated through their partner. This is a more difficult argument to apply to children who, in societies where they are required to attend school, do not have the potential to earn a wage to support themselves and are thus necessarily dependent economically upon parents or other adults who are responsible for their protection.

I am not arguing here that children should be entitled to social security in their own right, but rather that their lack of entitlement to this key social right because of their necessary economic dependence on adult protectors should not be used to devalue their claims to citizenship. As in feminist citizenship theory, what is at issue here is the status accorded economic independence through paid work as key to citizenship. Thus, while children's economic dependence, derived from their need for protection, may be incompatible with full rights as social citizens, it does not follow that children lose their claim to be active, participating citizens. The UNICEF report explains that

one of the most fundamental challenges posed by the Convention on the Rights of the Child is the need to balance children's rights to adequate and appropriate protection with their right to participate in and take responsibility for the exercise of those decisions and actions they are competent to take for themselves. ${ }^{104}$

It points to "the cultural change necessary so that children are protected appropriately in accordance with their evolving capacities, and also respected as citizens, as people, and as rights bearers." 105

103 Gill Jones \& Robert Bell, Balancing Acts: Youth, Parenting And Public POLICY 60 (2000).

104 LANSDOWN, supra note 25 , at 32.

105 Id. at xi. 
As Stasiulis argues, dependency arising from the need for protection is not incompatible with the right to participation: "A framework of rights that implies that only fully autonomous people may enjoy participation rights normalizes individual independence. . . . Indeed, the mutual reinforcement of protection and participation rights is integral to the model of children's citizenship advanced in the children's movement." ${ }^{106}$ Her critique of the normalization of independence chimes with a strand of feminist argument. Iris Young's ${ }^{107}$ distinction between independence as autonomy (the ability to make and act upon one's choices) and as self-sufficiency ("not needing help or support from anyone in meeting one's needs and carrying out one's life plans") is helpful here, for the autonomy associated with citizenship does not require an illusory self-sufficiency. Moss and Petrie point out that feminist arguments about human interdependence can be applied to children as well as adults. ${ }^{108}$ This claim is supported by Such and Walker's exploratory study, which indicated that "crucial components of responsibility were found to be its interdependence and relational nature." 109 In their discussion of children's dependence, Moss and Petrie endorse the feminist critique of "the normative image of the independent wage-earning citizen which is at heart of contemporary notions of social participation and citizenship." 110 The displacement of that normative image in feminist critiques is thus also relevant for children in education, whose claim to citizenship cannot, in industrialized societies, lie through wage-earning, even if some children do earn a part-time wage.

Furthermore (and this is a subsidiary argument), although children's dependence is a product of the care they receive, whereas women's stems from the care they provide, as observed earlier some children are also care-providers. As such, the work involved would be recognized as the exercise of citizenship responsibility in some feminist frameworks. Children

106 Stasiulis, supra note 64, at 513-14.

107 Iris M. Young, Mothers, Citizenship and Independence: A Critique of Pure Family Values, 105 ETHICs 535, 548 (1995).

108 Peter Moss \& Pat Petrie, Children - Who Do We Think They Are?, in CHILD WELFARE AND SOCIAL POLICY 85 (Harry Hendrick ed., 2005).

109 Such \& Walker, supra note 69, at 48.

110 Moss \& Petrie, supra note 108, at 85. 
(especially girls) may also help adult care providers in the home in various ways, particularly in two-earner and in lone parent families. ${ }^{111}$

\section{The Public-Private Divide and Power}

As in the case of women, the link between (in)dependence, care and children's citizenship is mediated by the public-private divide. Cohen draws the analogy between coverture, under which married women forfeited independent legal status, and the way in which children are "folded into the legal identity of their parents upon birth."112 So, she argues, "where women once ceded a public identity to their husbands and retreated (often reluctantly) to the private realm, children remain privatized by analogous forces." ${ }^{113}$ Similarly, in the same way that it was once considered permissible for men to inflict violence upon their female partners in the private sphere, so, in the UK, it is still lawful for parents to hit their children, albeit within legal limits.

Moreover, whereas women are now generally part of the public as well as the private sphere, commentators in the UK have pointed to how children are increasingly being excluded from public spaces (or are concentrated in adult-controlled spaces). In the case of younger children it reflects a growing protectiveness in the face of risk; in the case of older children, it is disorderly children who are seen as the risk to the wider community. Kulynych, too, observes that children "are segregated into their own space . . . [and] are physically denied a genuine public identity, and an opportunity to participate as citizens." ${ }^{114}$ Wyness et al. argue that children are "located within the hidden private sphere and at best viewed as political animals in potential." 115

Even more perhaps than feminist accounts, critiques of the construction of children's citizenship are centered on power relationships. Both women's and children's economic dependence are closely linked to unequal power relations. Women's and children's groups are both fighting for more power as citizens and both have, inevitably, encountered resistance. Hill and Tisdall suggest that "power is the main differentiating factor between children and

111 See Miller, supra note 71; Such \& Walker, supra note 69; Zelizer, supra note 71; Tess Ridge, Helping Out at Home: Children's Contributions to Sustaining Work and Care in Lone Mother Families, in CASH AND CARE 203 (Caroline Glendinning \& Peter A. Kemp eds., 2006).

112 Cohen, supra note 29, at 229.

113 Id.

114 Kulynych, supra note 35, at 254.

115 Wyness et al., supra note 12 , at 86. 
adults." ${ }^{116}$ Some inequality of power is perhaps inevitable in a way that it is not between adult women and men. Thus, Burke makes clear, in his critique of the notion of children as "citizens in the making," that he is "not suggesting that the citizenship young people 'enjoy' is the same citizenship that adults have" for the very reason that "in almost every circumstance young people have less power than adults and adult-run institutions, such as government."117

\section{Equal or Different?}

Burke's observation that young people's citizenship is not the same as that of adults brings us to a final parallel between the gendered citizenship and children's citizenship literatures: the question as to whether claims to citizenship are made on the basis of sameness/equality or difference. The argument for children's citizenship is predicated in part on a fundamental sameness and equality as human beings. ${ }^{118}$ Moreover, to state the obvious, children become adults, whereas women do not typically become men. Any arguments based on difference are therefore arguments that pertain only to a particular stage of the life-course. Nevertheless, these arguments are salient.

Moosa-Mitha asserts children's "rights to belong as 'differently equal' members of society, outside the private/public dichotomy that results in marginalizing children's interests and needs." ${ }^{119}$ She does so within the framework of a "difference-centred," feminist model of citizenship, which acknowledges the multiple subject positions occupied by citizens. Nevertheless, the appeal to equality also represents a claim on citizenship's universalist promise. I have suggested elsewhere that we can characterize such tensions between universalism and difference as a "differentiated universalism." ${ }^{120}$ Roche comments that "save for the 'child liberationists,' no one is arguing that children are identical to adults or that they should enjoy exactly the same bundle of civil and political rights as adults." ${ }^{121}$ Some rights are shared with adults in the form of human rights, some are particular to children in the form of children's rights and some citizenship rights are denied to children.

The notion of a "differentiated universalism" helps to capture children's particular relationship to both citizenship and human rights. It also provides

116 HiLl \& TisDaLl, supra note 28 , at 20.

117 Burke, supra note 15, at 52.

118 Ben-Arieh \& Boyer, supra note 50.

119 Moosa-Mitha, supra note 22, at 386.

120 LISTER, supra note 8, at 68-92.

121 Roche, supra note 23, at 487. 
a means of acknowledging the responsibilities they exercise and the ways these may simultaneously reflect both adult responsibilities and their own position as children. ${ }^{122}$ Following Roche, no one is arguing that children should exercise exactly the same bundle of responsibilities as adults - rather, again redolent of feminist arguments, that the responsibilities they do exercise should be recognized. Moreover, some advocates of "the imaginary of the active child citizen" ${ }^{123}$ acknowledge the dangers of casting participation as a responsibility for children. The right of the child not to participate must also be respected. Stasiulis, for instance, asks "does children's citizenship then tend to devalue the right of children to remain children with all its implications — such as playfulness, lightness and 'childishness'?"124 This is particularly important in the face of the growing tendency to treat children as adults in other spheres. Proponents of children's active citizenship need to be wary of subordinating children's right to be children (as understood in particular cultural contexts) to the higher calling of the demands of citizenship in the here and now in an instrumental way that mirrors the dominant construction of children as citizens of the future.

\section{CONCLUSION}

Returning to Hill and Tisdall's question posed at the outset, the conclusion reached from the above analysis is that we cannot discard "the building blocks of citizenship" in order to accommodate children. However, feminist critiques have shown how some of those building blocks can be re-shaped in order better to do so. A key move is to get away from the construction of substantive citizenship as an absolute - the idea that a person is either a citizen or she is not. That has been the purpose of this Article in unpacking the building blocks and analyzing children's citizenship in relation to each one of them. In doing so, it has revealed a second lesson: that the criteria for inclusion as citizens cannot be uniform and, for the same reason that they cannot be modeled on male norms, so they cannot be modeled on adult norms.

Various phrases have been deployed in the literature in an attempt to

122 Sharon Bessell, Children, Human Rights and Social Policy: Is Citizenship the Way Forward?, Paper Presented at Crawford School of Economics and Government Seminar Series, The Australian National University (May 9, 2006).

123 Stasiulis, supra note 64, at 507.

124 Id. at 509. 
capture the particular nature of children's citizenship. Roche ${ }^{125}$ advocates Bulmer and Rees' notion of "partial citizenship"126 as a means of avoiding either/or thinking. There are problems, though, with the way in which Bulmer and Rees apply the label of "partial citizenship" to women and people incapacitated in some way as well as to children. This fails to distinguish between the elements of partial citizenship that are more or less accepted as a corollary of a person's dependent status and those that are challenged as illegitimate such as in the case of women, minority ethnic groups, gays and lesbians and disabled people. Cohen uses the term "semi-citizenship" to denote children's "partial citizenship." She describes it as a "middle ground" in which children "are citizens by certain standards and not by others." ${ }^{127}$ Although the term "semi-citizenship" is itself problematic because of its connotations of inferiority, this characterization as a "middle ground" fits well with the approach taken in this Article and with the argument that citizenship cannot be reduced to just a bundle of rights, important as rights are.

I have elsewhere drawn a distinction between being a citizen and acting as a citizen:

[T]o be a citizen, in the legal and sociological sense, means to enjoy the rights of citizenship necessary for agency and social and political participation. To act as a citizen involves fulfilling the full potential of the status. Those who do not fulfil that potential do not cease to be citizens; moreover, in practice participation tends to be more of a continuum than an all or nothing affair and people might participate more or less at different points in the life-course. ${ }^{128}$

This formulation does not work for children. Rather, some children are deploying their agency and acting as citizens without first enjoying the full rights of citizenship. Again, if we analyze children's citizenship solely through the lens of rights, we miss much that is important to their experience of "lived citizenship" and to their claims to be recognized as citizens.

In fact, much of the literature that is making the case for recognition of children as citizens is not so much arguing for an extension of adult rights (and obligations) of citizenship to children but recognition that their citizenship practice (where it occurs) constitutes them as de facto, even

125 Roche, supra note 23.

126 Martin Bulmer \& Anthony M. Rees, Conclusion: Citizenship in the Twenty-First Century, in Citizenship Today 269 (Martin Bulmer \& Anthony M. Rees eds., 1996).

127 Cohen, supra note 29, at 234.

128 LISTER, supra note 8, at 42. 
if not complete de jure, citizens. It is also calling for adults to transform their relationship to children particularly in terms of respectful behavior and changes in the way participatory citizenship is practiced in order to accommodate children. Finally, it is challenging the idea that it is sufficient to treat children purely as citizens of the future.

Rights talk, particularly construed in terms of legal status, although necessary, is not sufficient either for the analysis of children's citizenship or for their political claims-making. Indeed, Kulynych goes so far as to argue that

excessive focus on rights in discussions of children's citizenship has actually disabled serious discussion of children as political actors. Right talk tends to exaggerate children's current citizenship status, overemphasizes formal, legal interpretations of political participation, and obscures the crucial need for recognition in authorizing children's citizenship. ${ }^{129}$

This perhaps overstates the case. Rights do represent a crucial underpinning to a more participatory and practice-oriented understanding of citizenship. Nevertheless, a focus on children's citizenship reinforces the case for a dialectical conceptualization of citizenship, which goes beyond that of a bundle of rights. It underlines the value of thinking in terms of "lived citizenship" as an element of children's developing identity. It also provides an answer to the question - "why citizenship?" - from the perspective of children. With its implications for belonging, identity formation and participation, citizenship as a rights-bearing status and a practice is "crucial for the well-being of human beings in general and for children in particular," as well as for the wider well-being and flourishing of society. ${ }^{130}$

129 Kulynych, supra note 35, at 232.

130 Ben-Arieh \& Boyer, supra note 50, at 33. It is particularly important for well-being in the Aristotlean "eudaemonic" sense of "the fulfilment of one's distinctively human potentialities" or "self-realization." THE OXFORD COMPANION TO PHILOSOPHY 908 (Ted Honderich ed., 1995). 